\title{
Functioning of Angel Investor Ecosystem in Turkey: A Study on Aegean Region Angel Investors
}

Elif Dursun

Dokuz Eylul University/MBA Student

Fahreddin Tekin

Dokuz Eylul University/MBA Student

Akın Karaosmanoglu

Ege University/MBA Student

\begin{abstract}
Turkey is at its infancy regarding the Angel Investment Ecosystem although it has a huge potential of Entrepreneurial Activities. There exist various alternatives for promoting start-ups or individual entrepreneurs such as KOSGEB, TOBB, bank loans, Incentives of Ministry of Economics, etc. However, those also come with strict procedures and bureaucracy which discourage the entrepreneurs having creative ideas. In this regard, angel investors are seemed to be the shortcuts to the actualization of the idea and the achievement eventually. Angel Investment Ecosystem in Turkey is also advantageous because it is backed up by Regulations published in 2013 (Individual Participation Capital Legislation published on 15 February 2013, in official newspaper of Turkish Republic). In this study, a broad history of Angel Investment Ecosystem in Turkey is analysed to form a pattern on Angel Investors' decision making process and angels' role on the actualization of entrepreneurial idea. We use samples from Aegean Region in which contains high potential of improvement in this Ecosystem. Angel Investors from Aegean Region and the entrepreneurs they have invested on are interviewed to gather information for understanding of how the angels decide and how the Ecosystem functions. Comments on findings and foresights for the future of angel investing in Turkey are presented as the conclusion.
\end{abstract}

Keywords: Angel Investment Ecosystem, Angel Investors, Decision Making Process of Angels, Entrepreneurship

\section{INTRODUCTION}

Entrepreneurship as an important fact for the welfare of economies has various challenges while starting up. One of the main challenges for the new entrepreneurs is finding financial resources. There exist different financing alternatives available to the start-ups, which could be grouped as formal (government related) and informal financing (mainly angel investors). Although the government tries to provide financial resources, this is not enough for new entrepreneurs. According to the previous researches, formal financing is much harder than the informal due to the fact that they require more bureaucracy, thus making it less preferable. Other issues are, formal financial resources cannot be provided to every sector, and the people who will evaluate it might not have the required qualifications to understand it although the business idea is very innovative and inspiring. At this point, the importance of angel investors emerges. Providing unique evaluation standards and their distance to bureaucratic procedures make angel investors very popular today. Angel investors generally invest in businesses that are new and, they look for value added products and services (Uckun, 2009).

Finding accurate data on angel investors is hard since it is quite private and not preferred to be released resulting from its personal nature of angel investors. Most of the data released in this area consist of estimations or derived from samples of previous studies of consulting firms. Pool of potential angel investors is 3-6 million individuals with net worth above $\$ 1$ million and it is reported that $25 \%$ of high net worth individuals are angels (Morrissette, 2007). According to Mason (2005), some $3.4 \%$ of the adult population in the 18 countries where information is available meet the definition of being an informal 
investor. They provide $\$ 196 \mathrm{~m}$ per year to new and growing companies, equivalent to $1.1 \%$ of the GDP of these countries, and accounting for between $60 \%$ and $90 \%$ of total venture capital, including institutional sources.

The angel market appears to be very heterogeneous and localized (Prowse, 1998). Therefore, generalizing the findings becomes harder as they differ in terms of demographics, experiences, psychological motivators, networks, and so on. With the diverse advantages, which angels provide for entrepreneurs, angels seem to be the best financing option for beginning stage of firms. There are many good examples of firms that are supported by angels as they start. Google, Apple, Amazon. com (Ibrahim, 2007), and Henry Ford (Morrissette, 2007) are among those examples.

In Turkey, business angels are very rare, and the history of angel investing does not go much back, which nearly has 12 year life-time till now. There are many alternative sources of finance for new entrepreneurs in Turkey such as KOSGEB, TOBB, bank loans, Incentives of Ministry of Economics, etc. However, those also come with strict procedures and bureaucracy which discourage the entrepreneurs having creative ideas. Therefore, Turkish entrepreneurs apply to the informal ways including family, relatives, friends, or business angel investors to start their business. Angel investors that will support the entrepreneur might be from the neighbourhood of entrepreneur as well as an unknown angel who is willing to invest. Turkey has a recently growing ecosystem of business angel network, and the characteristics of this ecosystem is a subject that needs to be researched for providing useful information to the future entrepreneurs and investors.

Therefore, this study aims to analyse Turkish business angel ecosystem to form a pattern on angel investors' decision making process, and to understand angels' role on the actualization of entrepreneurial ideas. Our paper consists of 3 Sections. In Section 1, we provide an overview of the literature including definition of business angels and the history of business angel ecosystem in Turkey. In Section 2, we explain our methodology, and release our findings. In Section 3, we provide our final comments on the findings by evaluating them within our literature review framework.

\section{LITERATURE REVIEW}

\section{Definition of Angel Investor}

The term angel investor originally referred to wealthy people who invested in Broadway productions. Today, however, angel investors do much more. "An angel investor is a person who provides capital, in the form of debt or equity, from his own funds to a private business, which is often an early-stage company but not exclusively, owned and operated by someone else, who is neither a friend nor family member" (Rodriguez, 2011).

Angel Investors are generally wealthy individuals, typically fellow entrepreneurs, willing to invest in the very early stages of a venture's development (Morrissette, 2007). Business angels are conventionally defined as high net worth individuals who invest their own money, along with their time and expertise, directly in unquoted companies in which they have no family connection, in the hope of financial gain (Mason, 2005).

According to another definition by PWC (2013), business angels are defined as affluent individual investors who invest their personal assets and/or experience and know-how to innovative, high-growth potential companies in need of seeding, startup or growth capital.

Typically, angel investors have the following characteristics in common (Uckun, 2009);

Those who earn more than 100,000 dollars,

40-60 years old,

Whose assets are more than $\$ 1,000,000$,

Have previous successful entrepreneurship experience,

Await return from the investment after 5-7 years - but some wants cash return within a couple of years after investment,

Prefer to invest in nearby locations. The travel time should not exceed the half of a day,

Enjoy mentoring and being a part of it

Invest over $\$ 150,000$, but this amount can also be the sum of the personal investments made by groups of other angel investors. 
Are willing to invest in industries they are familiar/experienced with/in,

Give importance to cash inflow and revenue,

Know the market and technology dynamics very well,

Are qualified as investors who provide added value and consultancy of money.

\section{Business Angel Investment Ecosystem in Turkey}

History of business angel investment in Turkey consists of a short period when compared to developed countries. This is due to the fact that Turkey has had log-lasting economic and financial crisis, instability of economy, and huge potential of risk for enterprises before the 2000s. Angel financing has emerged as an alternative tool to support start-ups when the economy has finally stabilized after 2000 (Bayar, 2012).

Angel investment has been brought into Turkey by LabX that has been established within Helix Yönetim Danışmanlık in 2006. It is established to serve as a bridge between angels and the entrepreneurs who do not have enough capital to actualize their business idea. As valid for the world, for Turkey also the actual data of angel investors and angel investment capital is not known precisely. The system of angel networks are recently transforming into institutionalized ecosystems, and various institutions has been performing as supportive organs for those angel networks/angels TUSIAD, Sabanci University, ODTU, etc. (Uluyol, 2008).

Within the fast growing younger population, Turkey carries high rate of entrepreneurial potential (nearly $60 \%$ ) and positive attitudes (nearly 70\%) towards entrepreneurship according to the results of Amway Global Entrepreneurship Report 2014. However, those rates decreased in 2016 report as $42 \%$ and 33\%. Also, according to another report from Oracle Capital Group (2014), Turkey is the second entrepreneurial country among 33 countries. Report also shows that Turkish entrepreneurs have low rate of fear to fail, they are risk takers, and attempted to self-fund.

Those aspects of entrepreneurs reveal reasons for emergence of business angels and they have an important role in supporting for pre-set stage of entrepreneurial activities. According to EBAN's European Early Stage Market Statistics 2015, Turkey has grown at 38\% rate between 2014 and 2015 in terms of total business angel investment, and has 15 business angel networks as of 2015. Report also displays a growing performance of angel investment networks. Active angel groups include (Altuntas, 2015):

Links Angel BAN

Galata BAN

Metutech BAN

Sirketortagim BAN

BUBA BAN

EGIAD BAN

$\operatorname{Lab} X$

Keiretsu Forum Istanbul

E-Tohum

BIC Angels

Within this framework, there have been four major developments in the Turkish angel ecosystem (Altuntas, 2016):

A new Angel Investment Law

A fast-developing angel investment community

Turkish Business Angel Association's (TBAA) global performance 
Attempts by Borsa Istanbul to create more liquidity for start-ups.

Government also supported those who support entrepreneurial activities to foster growth in this area and released Angel Investment Law in 2013. Article 1-(1) indicates the purpose of this law clearly as "The purpose of this regulation is to determine procedures and principles regarding the support for Business Angel Capital, a financial instrument for start-ups and early stage enterprises experiencing difficulties in access to finance due to high risk they have..." (Angel Investment Law, 2013).

The law aims to increase professionalism and ethics among angel investors, make angel investments more attractive through state support, and ultimately make angel capital an institutionalized and trustworthy source of finance. Under the law, the Turkish Treasury licenses business angels who want to benefit from tax incentives for their investments (Accredited angel networks can provide the license applications. ). Accordingly, $75 \%$ of the participation shares of qualifying Turkish resident joint-stock companies held by angels can be deducted from the angel's annual income tax base in the calendar year the shares are held (Altuntas, 2015).

Following qualifications are required for being accredited as a business angel (PWC, 2013): (1) Having high income or wealth (An annual gross income above TL200,000, or net assets above TL1 million), (2) Having experience (Two years of experience as a manager/director in a financial institution or a company with a TL25 million turnover, have one year of membership in a local business angel network with shares in three SMEs, or have TL20,000-plus investments in three technology companies supported by an incubator).

\section{METHODOLOGY AND FINDINGS}

In this research, a qualitative study has been carried out to form a pattern on how angel investors decide, how they help entrepreneurs to actualize their creative and innovative ideas, and how the ecosystem of business angels in Turkey functions. For this reason, we tried to unleash some specific characteristics of business angels first, and then analysed their decision processes. While analysing their investment decision processes, we have utilized from the Model of Angel Investment Process displayed in Exhibit 1. Due to the nature of subject, we conducted a qualitative research method. Our findings are derived from the in-depth interviews that we conduct with limited number of angel investors in Aegean Region. Also from our literature review, we could realize that previous researches' findings depend on qualitative research techniques to better understand the characteristics of angels.

\section{Exhibit 1: A Model of Angel Investment Process}

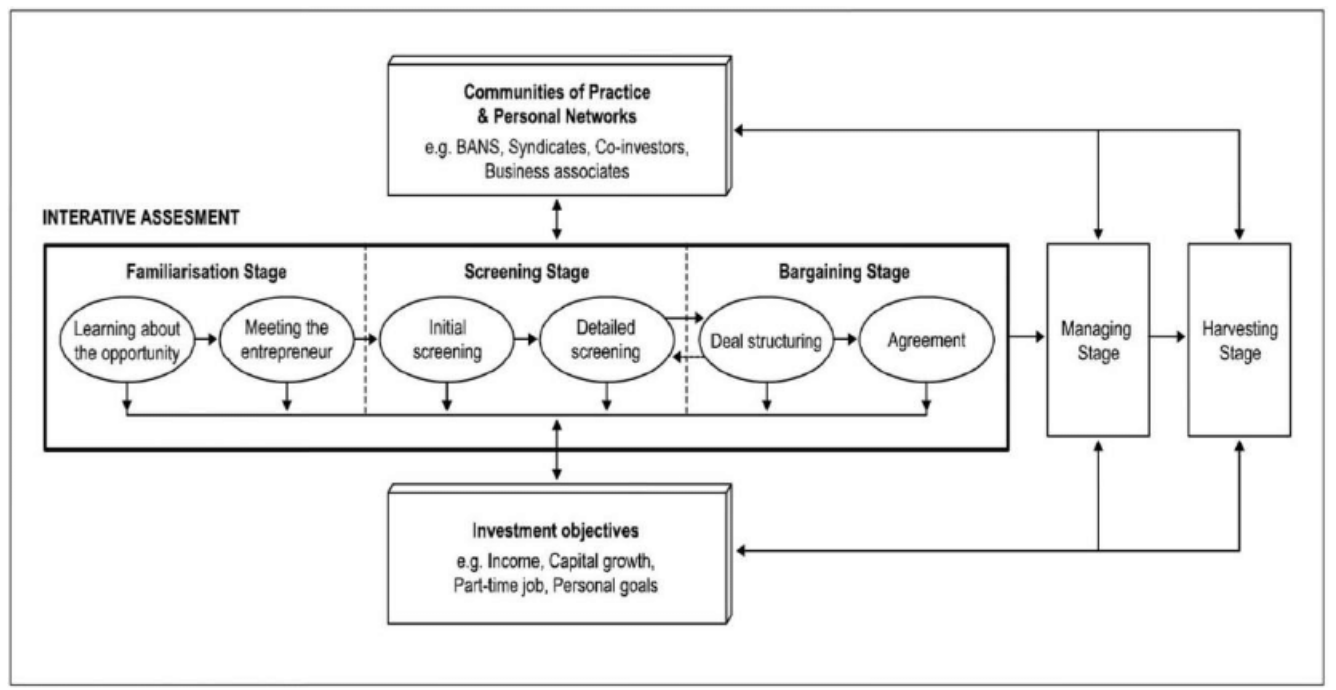

Source: Paul, Whittam, \& Wyper, 2007 
Major limitations to our study could be listed as (1) limited data and information about business angels released to the public, (2) unwillingness of business angels to be known or found by others, (3) investments done by angels are generally not recorded or not wanted to be recorded, (4) limited availability of contacts of business angels reached, (5) short time of business angel history in Turkey, and (6) limited number of formal angel networks in Turkey.

\section{Our Findings}

\section{How Angel Investors Decide?}

One of the main reasons triggering angels to invest is the return on investment they make. However, this is not the only motivation to get them invest on new entrepreneurs. As a result of our interviews with business angels, other factors motivating them to support entrepreneurial activities could be listed as followings:

Fostering entrepreneurship in Turkey to develop employment opportunities for the new generations. Cardon (2009) explains this as "the passion of entrepreneurship".

Fostering innovation and creativeness to enable sustainability in Turkish economy.

Being in a dynamic, energetic, and exciting atmosphere to enhance life experiences.

Being in an atmosphere where mutual learning - angel mentors entrepreneur, while entrepreneur provides innovative and creative ideas - occurs.

Supporting social entrepreneurship to provide benefits for the society.

Those projects that are nationally and internationally differentiate themselves attract the motivation of angels.

Developing more on their own business.

Fostering technological developments in Turkey to be able to produce our own high-tech products.

The stage of entrepreneurship (mostly the beginning stage or start-ups are supported) and the sector (those sectors the angel has experience mostly preferred to be invested) where it relates.

As Van Onasbrugge and Robinson (2000) evaluated the factors affecting investment decisions of angel investors in three categories, our findings show that angels have economic, social, and personal motivators while deciding on investments. Vance (2005) says that there are 4 basic factors that angels consider while investing, (1) Characteristics of entrepreneur, (2) Features of project, (3) Content of deal they make with entrepreneur and (4) Individual expectations of angels from both entrepreneur and project. When we review other findings of researches done on this subject, we see that personal motivators also have an important role on decision making process (Wetzel, 1982; 1983). Etzioini (1988) in his study pointed out that angels are driven by others' pain/hardships as much as their own interests while investing on a projects. Wiltbank, et al. (2009), has found out that angels take important roles on management, marketing, and decision processes along with financial supports. They also support the entrepreneur within the borders of their experiences and know-how. Sudek (2007) in his study, states that angels also act as full or part-time consultant.

\section{How Angel Investors Help Entrepreneurs to Actualize Their Idea?}

Angels' main role could be identified as, to decide how much to invest, how much to own in the investment return/management, and how much funding and what kind of sourcing to obtain in later stages of invested projects (Elitzur \& Gavious, 2003). However, they might have different roles further than those.

Especially those angels, who would prefer to be actively engaged in the project, help entrepreneurs to bring their projects into action from different aspects other than financial funding only. Our findings about the subjects they help are as the followings:

Our first observation gathers around managerial and mentoring activities that angels provide. 
At the beginning stages, one of the investors state that they were engaged in daily managerial activities but as the business grows, angel could only act within managerial boards as mentor and controller.

Another angel states that, he helps preparing business plans, tracking of processes, internal auditing, and management issues.

Another says, "rather than daily activities, I play at the backstage as a mentor on business strategies and managerial issues, but this also depends on capabilities of entrepreneur. Watching from behind and mentoring accordingly is my major role."

Our second observation gathers around the benefit angels provide on marketing \& sales activities.

Most of the angels have commented on this subject as they mainly help with strategic decisions of marketing activities, preparing marketing strategies \& marketing plans, conducting PR activities, and finally they allow entrepreneurs to benefit from their network.

Our third observation is on business knowledge, expertise, and network of angels. Angels mostly prefer to invest on sectors that they have previous experience, they are familiar with. Therefore, they do not hesitate to share their know-how with entrepreneur to better develop and have positive returns on investments they make.

Our forth observation shows that angels also consider later stages \& sustainability of projects, and make effort to help entrepreneurs reaching proper sources of funding, financial help, incentives, and other supports provided for start-ups such as KOSGEB incentives etc. Most of the angels state that they actively follow news on incentives and different kinds of financing alternatives available on the sectors, and then inform entrepreneurs to benefit from those alternatives.

Our last observation is about the human resource of projects. As we state in our third observation, angels make available their networks to the entrepreneurs. These networks are also useful in terms of HR perspective of start-ups. Angels are also providing proper employment of key people to the required positions. One of the angels says, he especially acknowledges that a strong team would overcome many difficulties and uncertainties, therefore he proposes possible candidates to the key positions. Another angel goes a bit further and says that they have active role on employment processes such as review of resumes, interviewing the candidates, and giving orientations to the filled positions. However, some angels prefer not to intervene with this issue a lot, and leave the team building to the entrepreneur.

Our findings are also supported by other research findings. Angel investors, are not only provider of financial resources, but also they share the information necessary for the entrepreneurs (Kuratko, 2009). Angel investors act as management support and trainer, and are also effective in decisions taken on important issues (Sakaryali, 2014). Angel investors provide benefits to entrepreneurs from their own network, take part in management, recruitment and training and actively involved in the supply of resources (Karabayir, et al. 2012). Angel investors are successful entrepreneurs who are looking for different investing fields, and business ideas (Osnabrugge, 2000). They are also considering the personal qualities and characteristics of the entrepreneur (Harrison and Mason, 2002). Angels also may help solve major operational problems, evaluate capital expenditures, and develop the company's long-term strategy. They may often take a formal position as a paid part-time or full-time consultant to the firm (Prowse, 1998).

\section{Main Findings on Characteristics of Angels}

From our findings we could define different profiles of angel investors:

One of the profiles would be profit seeking angels who actually consider the return on investment more than any other motivating factors to invest. They pay more attention on financial return in short term (1 or 2 year) or growing their own businesses. Their first concern would be the break-even point in assessment process of project rather than other benefits to the society or economy. They take no chance on risky projects, and they do act according to concrete pictures. If they realize that the project will be profitable in the long run, they prefer to hold major ownership and control of project, thus take most of the profit.

Second profile would be opportunistic angels who always seek out different and innovative ideas/projects to invest on. Those angels generally follow trends and dynamics of market, and search for entrepreneurs that make themselves remarkable on this market. While doing this, angels use different kinds of channels such as national/international entrepreneurship resources such as Wall Street Journals, etc., news from pioneer schools and universities on this subject, websites, blogs, conferences, fairs, etc. 
Third profile would be active angels who take part in the organization as if they are the entrepreneur. Those angels help entrepreneurs at almost every issue from management to the marketing, recruitment, PR, accounting/financing, and consultancy. They become simply a part of project and try to enhance it further as well as sustainability. However, we could not define an opposite of this term for angels as passive in Turkey because, this term could be confused with sponsorship. Prowse (1998) defines passive angels as those who provide only money and rarely monitor the firm closely. For Turkey, this is very rare that we could say even do not exist, because most of the angels wants to be informed and aware of current position of their investment. Therefore, they actively take part in at least management. Passive angel definition could be match with sponsorship term in Turkey, because sponsorship organizations or bodies do not take part in any activity after they give financial support to the start-ups.

Our last profile would be risk taker angels who invest on new/untried ideas. Angels state that they find exciting to give chance for untried ideas, which they also think it would survive in the market. Angels are also aware that those ideas that have been tried before have low margins, low return, strict entry rules, and low share among market. Therefore, taking their chance on new start-ups is most preferred by angel investors. Also the statistics of fear of failure, and risk taking from Oracle Capital Group's 2014 report supports that both angels and entrepreneurs are generally fit into this profile.

\section{CONCLUSION AND COMMENTS}

From our literature review and findings, we see that angel investment ecosystem is recently developing in Turkey, and more effort on this area is needed to catch up with developed countries. There are various advantages of angel investing for the economy and entrepreneurs such as providing added value and providing mentorship to the start-ups as well as financing. On the other hand, it might also be disadvantageous if the angel is to be profiteer, harming the creativeness and sustainability of projects along with discouraging entrepreneurs.

We see that there are different profiles of angels in business angel ecosystem in Turkey. This is could also be harmful and confusing for the entrepreneurs to find the right angel investor for actualization of their projects in a way that they missioned. For example, the social entrepreneurs would be taken to different points if they could not match with the correct angel profile, when as those projects could be beneficial for the angel, the entrepreneur, and the society.

Other important issue is the sectors that angels focus on. We see that angels follow the investment and entrepreneurship trends nationally and internationally. This is very advantageous for the entrepreneurs to be more creative and different from others. However, here there exist some ignored areas such as environmental issues. Most of the angels focus on technology investments but ignore agricultural and environmental issues of future. When we consider that there will be extinction of species, limited resources, and environmental problems, angels should also direct their investments on those kinds of entrepreneurial projects.

According to our findings, angels have active roles on helping entrepreneurs to make their projects actual and profitable. There are different areas they help such as management, marketing, mentoring, and so on. Those are important for the entrepreneurs because they will be like a child in a sea for the first time when they enter into the market with their projects. Angels are like swimming trainers for those entrepreneurs. Therefore, those benefits provided by angels are very essential to the survival \& sustainability of projects. If those benefits are properly utilized by entrepreneurs, it will probably double the return of investment and satisfy expectations of both parties.

Today, it is easier to reach investors or entrepreneurs since the networks and contact channels are very developed with the technology. There are different platforms that make it available to meet with angel investors and entrepreneurs. Some of those platforms are e. g. conferences, competition events, fairs, web sites of angel networks. Therefore, angels and entrepreneurs should follow those kinds of meeting points for correct matching.

As Exhibit 1 display, there are different stages that entrepreneurs and angels pass through. However, this process is more informal in Turkey. Those stages are not exact and lived during the actualization of projects. Also those stages would have different life-time according to the matching of parties. If entrepreneur is matched with the appropriate angel, this stages and time would be lessened. Therefore, entrepreneurs should be careful while selecting their angels or vice versa.

Our suggestions for the entrepreneurs would be to carefully analyse expectations and capabilities of angels. They should be demanding and aware of their own competitive advantages when compared to their rivals. They should prepare realistic 
business plans that clearly present future of project to convince angels for investment decision. They should carefully consider motivating factors for angel investors as we state in our findings.

This study is an escalator to form a proper model of angel investors decision processes in Turkey because the ecosystem of angels differ from other countries in terms of cultural aspects. Therefore, these aspects are important to be studied for a better understanding of this ecosystem. This subject is important to be understood because it carries huge importance for the welfare of country as well as society in terms of fostering employment and innovative entrepreneurial ideas that would reveal societal benefits.

\section{References}

[1] Altuntas, B. (2015). Chapter 14 in Angels without Borders Trends and Policies Shaping Angel Investment Worldwide, Turkey Section, pp. 151-155 from World Scientific Publishing Co. Pte. Ltd.

[2] Altuntas, B. (2016). Early Stage Investment in Europe Today - What Incentives Do Business Angels Need? The European Trade Association for Business Angels, Seed Funds, and other Early Stage Market Players (EBAN) \& Hellenic Business Angels Network (HEBAN). July, 2016.

[3] Amway Global Entrepreneurship Report 2014 \& 2016. Accessed at http://www. amwaytoday. com. au/Business_News/Amway_News/

[4] Bayar, Y. (2012). Girişimcilik Finansmanında Risk Sermayesi ve Melek Finansmanı. Girişimcilik ve Kalkınma Dergisi (7:2) 2012, pp. 133-144.

[5] Branscomb, L. M. and Philip, A. (2002). Between Invention and Innovation: An Analysis of Funding for EarlyStage Technology Development. Prepared for Economic Assessment Office, Advanced Technology Program, National Institute of Standards and Technology.

[6] Cardon, M. S., Sudek, R. and Mitteness, C. (2009). The Impact of Perceived Entrepreneurial Passion on Angel Investing. Frontiers of Entrepreneurship Research 29(2): 1-15.

[7] EBAN, Statistics Compendium 2015. European Early Stage Market Statistics. Published in May 2016.

[8] Elitzur, R. \& Gavious, A. (2003). Contracting, Signaling, and Moral Hazard: A Model of Entrepreneurs, 'Angels,' and Venture Capitalists. Journal of Business Venturing 18 (2003) 709-725. Elsevier Science Inc.

[9] Etzioni, A. (1988). The Moral Dimension: Towards a New Economics. The Free Press, New York.

[10] Global Entrepreneurial Report (2014). Oracle Capital Group, 8-12 Welbeck Way London, UK. OnlineAccessed at http://orcap. co. uk/category/surveys/

[11] Harrison, R. T. and Mason, C. M. (2002) Backing the Horse or the Jockey? Agency Costs, Information and the Evaluation of Risk by Business Angels. Paper presented at the 22nd Babson College - Kaufman Foundation Entrepreneurship Conference, University of Colorado at Boulder, 6 - 8 June.

[12] İbrahim, D. M. (2007). The (Not So) Puzzling Behavior of Angel Investors. Vanderbilt Law Review, Vol. 61:5:1405:2008. Retrieved from http://ssrn. com/abstract=984899

[13] Karabayir, E. M., Gulsen, A. Z., Ciftci, S. \& Muzaffar, H. (2012). The Role of Entrepreneurial Orientation on Angel Investors' Investment Decisions: A Study of Turkish Angel Investors. Ankara Universitesi. 67(2) 69-93.

[14] Kuratko, D. F. (2009). Entrepreneurship: Theory, Process, and Practice, Ninth Edition, South-Western.

[15] Mason, C. M. (2005). Informal Sources of Venture Finance. Hunter Centre for Entrepreneurship \& University of Strathclyde, Glasgow G1 1XH, United Kingdom. Revised in August 2005.

[16] Mayfield, W. (2000). What is Informal Venture Capital and Who are Angels?. Kansas Economic Report, Spring 2000, 28, Wichita State University, Wichita, Kansas. 
[17] Morrissette, S. G. (2007). A Profile of Angel Investors. The Journal of Private Equity. Euromoney Institutional Investor PLC. Summer 2007.

[18] Osnabrugge, M. V. (2000). A Comparison of Business Angel and Venture Capitalist Investment Procedures: An Agency Theory-Based Analysis. Venture Capital, 2 (2): 91-109.

[19] Osnabrugge, M. V. and Robert J. R. (2000). Angel Investing: Matching Start-up Funds with Start-up Companies: The Guide for Entrepreneurs Individual Investors and Venture Capitalist. Jossey-Bass, San Francisco

[20] Paul, S., Whittam, G., \& Wyper, J. (2007) Towards a Model of the Business Angel Investment Process. Venture Capital, 9 (2), $107-125$

[21] Prowse, S. (1998). Angel Investors and the Market for Angel Investments. Journal of Banking \& Finance, 22 (1998) 785-792. Elsevier Science B. V.

[22] PWC- Yalçın, B., et al. (2013). Business Angels in Turkey. Asset Management Bulletin. PricewaterhouseCoopers Turkey. February 2013.

[23] Rodriguez, E. M. (2011). Angel Financing: Matching Start-Up Firms with Angel Investors. Claremont McKenna College. CMC Senior Theses. Paper 136. Retrieved from http://scholarship. claremont. edu/cmc theses/136

[24] Sakaryali, D. A. M. (2014). Innovation and Venture Capital. Journal of Entrepreneurship and Development. 9(11). 183-210.

[25] Sudek, R. (2007). Angel Investment Criteria. Journal of Small Business Strategy,17(2): 89-103.

[26] Uckun, N. (2009). "KOBi'lerin Finansal Sorunlarına Melek Sermaye Çare Olabilir mi?" Muhasebe ve Finansman Dergisi, Sayı 41, Ocak,121-130.

[27] Uluyol, O. (2008) Girişimcilikte Alternatif Bir Finansman Modeli Olarakmelek Finansman Yöntemi. Sustainable Competition and Resource-Based View in Global Markets. Girişimcilik ve Kalkınma Dergisi, Cilt 3, Sayı 2, 4368. ;

[28] Vance, D. E. (2005). Raising Capital. Springer Press, Camden, New Jersey.

[29] Wetzel, W. E. (1982). Risk Capital Research. Encyclopaedia of Entrepreneurship, Kent, Calvin A., Donald L. Sexton and Karl H. Vesper (eds. ), Prentice Hall, Englewood Cliffs, New Jersey.

[30] Wetzel, W. E. (1983). Angels and Informal Risk Capital. Sloan Management Review, 24 (4): 23-34.

[31] Wiltbank, R., Stuart, R., Nicholas, D., and Saras D. S. (2009). Prediction and Control under Uncertainty: Outcomes in Angel Investing. Journal of Business Venturing, 24 (2): 116-133. 